\title{
PORTFOLIO MANAGEMENT IN LIC- AN EMPIRICAL STUDY OF DHARWAD REGION
}

\author{
*Jyoti.M.Goudar \\ Research Scholar, \\ PG Dept. of commerce, \\ Karnatak University Dharwad,
}

\author{
***Prof.S.S.Hugar \\ Professor of Commerce, \\ Professor, \\ Karnatak University Dharwad
}

Article DOI: https://doi.org/10.36713/epra4700

\begin{abstract}
LIC of India is the leading insurance company in India. Life insurance is designed to protect life and to protect family against financial uncertainties that may result due to unfortunate demise or illness. It can also view as a comprehensive financial instrument, as a part of the financial planning offering savings \& investment facilities along with cover against financial loss. By choosing the right policy as per the needs. We all have different financial needs and objectives. But life insurance plays a fundamental role in most of our plans for financial security. That's because of the variety of life insurance plans available and the many ways they can be customized to meet unique needs at different periods of our life.

The present study is concerned with investment portfolio of life Insurance Company during the period 2017-20. The gist of this paper is to examine and explain different investment portfolio of the life insurance company. Moreover to find out how they follow the prevailing norms of investment guideline and to signify the deviation from investment norms. Therefore, it becomes relevant to discuss investment portfolio at the outset with the help of csome statistical test i.e. ChiSquare, percent, trend etc.
\end{abstract}

KEY WORDS: Portfolio analysis, Life insurance, Investment guidelines, Customers.

\section{INTRODUCTION}

A Company's primary objective is to develop products that satisfy the customer's needs. The company's existence is in trouble if it does not deliver need satisfying product / service. The concept of product extends the applicability of marketing principles to insurance marketing. "A product is anything that can be offered to a market for attention, acquisition, use or consumption that might satisfy a want or need. It includes physical objects, services, persons, places, organizations and ideas. "Philip Kotler describes insurance products as unsought (consumer) goods". These are consumer goods that the consumer does not know about or knows about but does not normally think of buying." Product element in the financial services is of the outmost importance, since the customer is initially attracted to the product only. The benefits of the financial services must be of value to the customer.

A portfolio manager is a professional responsible for making investment decisions and carrying out investment activities on behalf of vested individuals or institutions. The investors invest their money into the portfolio manager's investment policy for future fund growth such as a retirement fund, endowment fund, education fund, or for other purposes 7 . Portfolio managers work with a team of analysts and researchers, and are responsible for establishing an investment strategy, selecting appropriate investments, and allocating each investment properly towards an investment fund or asset management vehicle ${ }^{6}$.

The things which involves in Portfolio Management are as follows;

\section{Allocation of assets}

This is the base for portfolio management where assets with low correlation with each other are mixed in a certain way so that the risk and return profile of the investor are Investors who have huge risk appetite can settle for a more volatile group of 
assets while the risk-averse investors can go for subtle or stable investment classes.

\section{Diversification of investment}

Since, it is not possible for any investor, portfolio manager to predict how one single asset class will behave or return over a longer period of time due to various ambiguities in the market and the volatility, diversification is necessary. It is to divide the amount invested, in different asset classes, which are least correlated with each other.

\section{Investment/asset rebalancing}

Since markets are not same every year; the asset allocation needs to be rebalanced according to the market prediction for the similar period. Another scenario is over the period of time, the ratio of asset classes in the portfolio changes on its own due to the returns accumulated. For example, in the beginning, you invested $60 \%$ in shares and $40 \%$ in FDs but with the passage of time, the ratio changed to $75: 25$ ratios which have put your investment at risk. The portfolio manager keeps an eye on the portfolio and whenever he or she feels that the portfolio has crossed the level of the risk appetite of the investor, they rebalance it accordingly.

\section{REVIEW OF LITERATURE}

A good number of studies have been made by researchers, academicians and other experts in the area of life insurance companies to measure the product portfolio management in LIC. Some important studies conducted in this area which is mentioned here.

Mundra (2000) ${ }^{1}$ expressed, through his article, the fear in the minds of the competitors and the possible strategies to face them. The main concern of the public sector companies, according to him, is that the private players, especially foreign ones, will swamp the market and grab a large share of it. The possible strategies for combating the situation can be the adoption of latest information technology, use of data warehousing management, implementation of high level training and development programmes and practices of alliances and tie-ups.

Nikhil Gupta (2001) $)^{2}$ in his article viewed that among the strategies that Indian insurers adopt, best opportunity lies in the product's core function that is in providing a safety net. The author brings out the highlights in rising proportional aspects, penetration level and other projected macro - factors along with global insurance market during the year 1999. Protection is discussed separately with their capital base, centre owned, number of agents and free look period.

Ziaudeen, A. (2003) ${ }^{3}$ in his dissertation he had discussed various aspects relating to product line, product development process, product mix, premium fixation, modification, facilities provided to policyholders, accessibility of Life Insurance Company services in Thanjavur location, training, motivation and the problem involved in it. He suggested that the level of awareness among the consumers has to be improved more in order to tap the market entirely.

Varaprasad, V. and Murali Krishna, B. (2009) ${ }^{4}$ were in their article revealed that the suggestions brought forward by this study are mixed. The contribution of insurance sector to economic development hardly affects financial intermediation. He concluded that in order to make insurance sector significant component of financial intermediation process, complete deregulation and increase in face of reforms are essential at the same time, by adopting proper segmentation capture significant share in the market for the overall benefit of organizations.

R Guru Murthy(2012) 5 in his article on said that with the opening up of Insurance Sector, more private players started entering the Industry with new products and new marketing strategies. The researchers want to conclude that the marketing strategy should have to be adopted cautiously after studying various parameters such as customer expectations and Perceptions into account.

\section{OBJECTIVES OF THE STUDY}

1. To know the marketing approach in relation to life insurance.

2. To through light on the marketing strategies to improve customer service and policy services.

3. To analyse the significant relation in between strategic marketing approaches and product portfolio mix in LIC.

\section{HYPOTHESIS}

$\mathbf{H}_{0}$ : There is no significant relation in between strategic marketing approaches and product portfolio mix in LIC.

$\mathbf{H}_{\mathbf{1}}$ : There is significant relation in between strategic marketing approaches and product portfolio mix in LIC.

$\mathbf{H}_{0}$ : There is no significant relation in between selling the policy by the agents or officers and convincing the policyholders, sufficient staff and computerised work.

$\mathbf{H}_{1}$ : There is significant relation in between selling the policy by the agents or officers and convincing the policyholders, sufficient staff and computerised work.

$\mathbf{H}_{0}$ : There is no significant relation in between policyholders' financial needs and LIC insurance plans. 
$\mathbf{H}_{1}$ : There is significant relation in between policyholders' financial needs and LIC insurance plans.

\section{RESEARCH METHODOLOGY}

a. Collection of data: The study based on primary and secondary data. The primary data has been gathered by the execution of well structured questionnaire to the respondents. And the secondary data has been collected from the published records of company i.e. annual reports, journals, books etc.

b. Tools of analysis: The collected data recorded, analyzed and interpreted in the significant manner with the help of SPSS and excel sheet. The statistical tools used for the study included percent, ratio and Chi-square etc.

c. Sampling Area: This study is based on empirical research. The corner stone is to analysis investment portfolio of Life Insurance Corporation of India.

d. Period of study: The data was collected during the period 2016-19

\section{RESULTS AND DISCUSSIONS}

Table No. 1 Respondents opinion about Demographic profile:

\begin{tabular}{|c|c|c|c|}
\hline Demographic & Groups & Frequency & Percent \\
\hline \multirow[t]{3}{*}{ Gender } & Male & 67 & 67.0 \\
\hline & Female & 33 & 33.0 \\
\hline & Total & 100 & 100.0 \\
\hline \multirow[t]{4}{*}{ Education } & Graduation & 64 & 64.0 \\
\hline & Post-Graduation & 34 & 34.0 \\
\hline & Others & 2 & 2.0 \\
\hline & Total & 100 & 100.0 \\
\hline \multirow[t]{4}{*}{ Age } & 30 to 40 years & 29 & 29.0 \\
\hline & 41 to 50 years & 30 & 30.0 \\
\hline & 51 to 60 years & 41 & 41.0 \\
\hline & Total & 100 & 100.0 \\
\hline \multirow[t]{3}{*}{ Marital status } & Married & 92 & 92.0 \\
\hline & Unmarried & 8 & 8.0 \\
\hline & Total & 100 & 100.0 \\
\hline \multirow[t]{6}{*}{ Work experience } & Less than 5years & 11 & 11.0 \\
\hline & 6-10 years & 8 & 8.0 \\
\hline & 11-15 years & 16 & 16.0 \\
\hline & $16-20$ years & 24 & 24.0 \\
\hline & More than 20 years & 41 & 41.0 \\
\hline & Total & 100 & 100.0 \\
\hline
\end{tabular}

Table No.1 Depicts information about demographic profile of respondents. It clear from the above table that, $67.00 \%$ of respondents are male and remaining $33.00 \%$ of respondents are female. However $64.00 \%$ of respondents are graduates and $34.00 \%$ are post graduates; and remaining $02.00 \%$ are others. Whereas $41.00 \%$ of respondents belong to 51 to 60 years of age group followed by $30.00 \%$ of respondents belong to 41 to 50 years and remaining $29.00 \%$ of respondents belong to 30 to 40 years of age groups. It is noticed that $92.00 \%$ of respondents are married and remaining $08.00 \%$ of respondents are unmarried. However $41.00 \%$ of respondents are having more than 20 years of experience; $24.00 \%$ of respondents are having 16 to 20 years of experience; $16.00 \%$ of respondents are having 11 to 15 years of experience; $11.00 \%$ of respondents are having less than 5 years of experience and remaining $08.00 \%$ of the respondents having 6-10 years of work experience.

At last it may be inferred that, LIC is having highly experienced, qualified and office staff, hence this may be the real strength of LIC with which it's doing good business in the market. 
EPRA International Journal of Multidisciplinary Research (IJMR) - Peer Reviewed Journal Volume: 6 | Issue: 6 | June 2020 || Journal DOI: 10.36713/epra2013 || SJIF Impact Factor: 7.032 ||ISI Value: 1.188

Table No. 2 Respondents opinion about marketing approach in relation to life insurance:

\begin{tabular}{|c|c|c|c|c|c|c|c|c|c|}
\hline Sl.No. & Marketing approach & & SDA & DA & $\mathbf{N}$ & $\mathbf{A}$ & SA & $\mathbf{M}$ & SD \\
\hline \multirow[t]{2}{*}{1.} & \multirow{2}{*}{$\begin{array}{l}\text { Research to determine } \\
\text { customers financial } \\
\text { security }\end{array}$} & $f$ & 0 & 9 & 15 & 42 & 34 & \multirow{2}{*}{4.01} & \multirow{2}{*}{0.93} \\
\hline & & $\%$ & 0 & 9.0 & 15.0 & 42.0 & 34.0 & & \\
\hline \multirow{2}{*}{2.} & \multirow{2}{*}{ Design new services } & $f$ & 0 & 0 & 0 & 59 & 41 & \multirow{2}{*}{4.41} & \multirow{2}{*}{0.49} \\
\hline & & $\%$ & 0 & 0 & 0 & 59.0 & 41.0 & & \\
\hline \multirow[t]{2}{*}{3.} & \multirow{2}{*}{$\begin{array}{l}\text { Market services to the } \\
\text { customer for whom they } \\
\text { were researched and } \\
\text { designed at a profit }\end{array}$} & $f$ & 0 & 0 & 16 & 50 & 34 & \multirow[t]{2}{*}{4.18} & \multirow[t]{2}{*}{0.69} \\
\hline & & $\%$ & 0 & 0 & 16.0 & 50.0 & 34.0 & & \\
\hline \multirow{2}{*}{4.} & \multirow{2}{*}{$\begin{array}{l}\text { Satisfy the customer's } \\
\text { needs }\end{array}$} & $f$ & 0 & 9 & 0 & 6 & 85 & \multirow{2}{*}{4.67} & \multirow{2}{*}{0.88} \\
\hline & & $\%$ & 0 & 9.0 & 0 & 6.0 & 85.0 & & \\
\hline
\end{tabular}

Note: SA-Strongly Agree, A-Agree, N-Neutral, DA-Disagree, SDA-Strongly Disagree

Table No. 2 exhibits the information regarding respondents' opinion about marketing approach in relation to life insurance. There are four marketing approaches identified and collected opinion on these four marketing approaches from the officers on five point Likert scale. The average opinion of officers on all marketing approaches is above 4 which indicates officers agree and strongly agree with all four marketing approaches. The standard deviation below one indicates the opinion was consistent.

In toto it can be inferred that all the above four marketing approaches have been taken into consideration while forming the policies. It may be due the reason that the marketing approaches will have very important role to play to frame any policies keeping in mind of financial security, new service design, profit and satisfaction of policy holders.

Table No. 3 Respondents opinion about marketing strategies to improve customer service and policy services:

\begin{tabular}{|c|c|c|c|c|c|c|c|c|c|}
\hline Sl.No. & Marketing strategy & & SDA & DA & $\mathbf{N}$ & A & SA & $\mathbf{M}$ & SD \\
\hline \multirow{2}{*}{1.} & \multirow{2}{*}{$\begin{array}{l}\text { A very clear definition of } \\
\text { marketing objectives }\end{array}$} & $\boldsymbol{f}$ & 0 & 0 & 0 & 30 & 70 & \multirow{2}{*}{4.70} & \multirow{2}{*}{0.46} \\
\hline & & $\%$ & 0 & 0 & 0 & 30.0 & 70.0 & & \\
\hline \multirow{2}{*}{2.} & \multirow{2}{*}{$\begin{array}{l}\text { A very clear definition of target } \\
\text { customers }\end{array}$} & $f$ & 0 & 0 & 0 & 72 & 28 & \multirow{2}{*}{4.28} & \multirow{2}{*}{0.45} \\
\hline & & $\%$ & 0 & 0 & 0 & 72.0 & 28.0 & & \\
\hline \multirow[t]{2}{*}{3.} & \multirow{2}{*}{$\begin{array}{l}\text { The development of marketing } \\
\text { needs to satisfy the customers at } \\
\text { a profit }\end{array}$} & $f$ & 0 & 0 & 0 & 50 & 50 & \multirow{2}{*}{4.50} & \multirow{2}{*}{0.50} \\
\hline & & $\%$ & 0 & 0 & 0 & 50.0 & 50.0 & & \\
\hline \multirow{2}{*}{4.} & \multirow{2}{*}{$\begin{array}{l}\text { Planning for each of the 'source' } \\
\text { markets and each of the 'use' } \\
\text { markets }\end{array}$} & $\boldsymbol{f}$ & 0 & 0 & 1 & 67 & 32 & \multirow{2}{*}{4.31} & \multirow{2}{*}{0.49} \\
\hline & & $\%$ & 0 & 0 & 1.0 & 67.0 & 32.0 & & \\
\hline \multirow[t]{2}{*}{5} & \multirow{2}{*}{ Organization and administration } & $f$ & 0 & 0 & 9 & 8 & 83 & \multirow{2}{*}{4.74} & \multirow{2}{*}{0.61} \\
\hline & & $\%$ & 0 & 0 & 9.0 & 8.0 & 83.0 & & \\
\hline
\end{tabular}

Note: SA-Strongly Agree, A-Agree, N-Neutral, DA-Disagree, SDA-Strongly Disagree

Table No. 3 crystallizes the information about respondents' opinion regarding marketing strategies to improve customer service and policy services. There are five marketing strategies identified and collected opinion on these five marketing strategies from the officers on five point Likert scale. The average opinion of officers on all marketing strategies is above 4 which indicates officers agree and followed by strongly agree with all four marketing strategies. The standard deviation below one indicates the opinion was consistent. 
At the end it can be inferred that LIC officials take into consideration all the above five marketing strategies to improve customers service and policy services. It may be due to the reason that, it is marketing strategies which will be having a pioneer role to play to provide good services to customers and their policies services too to remain competent in the market.

Table No. 4 Respondents' opinion about officers Perception on the strategies followed to form marketing mix to sell the insurance products and services:

$\mathrm{H}_{0}$ : There is no significant relation in between strategic marketing approaches and product portfolio mix in LIC. in LIC.

$\mathbf{H}_{1}$ : There is significant relation in between strategic marketing approaches and product portfolio mix

\begin{tabular}{|c|c|c|c|c|c|c|c|c|c|c|c|}
\hline $\begin{array}{l}\text { Sl. } \\
\text { No. }\end{array}$ & Strategies & & $\begin{array}{c}\text { SD } \\
1\end{array}$ & $\begin{array}{l}\text { D } \\
2\end{array}$ & $\begin{array}{c}\text { SW } \\
\text { D } \\
3\end{array}$ & $\begin{array}{l}N \\
4\end{array}$ & $\begin{array}{c}\text { SW } \\
\text { A } \\
5\end{array}$ & $\begin{array}{l}\text { A } \\
6\end{array}$ & $\begin{array}{c}\text { SA } \\
7\end{array}$ & $\mathbf{M}$ & SD \\
\hline \multirow{2}{*}{1.} & \multirow{2}{*}{$\begin{array}{l}\text { LIC offers a variety Product mix to } \\
\text { Policyholders }\end{array}$} & $f$ & 0 & 0 & 0 & 0 & 5 & 33 & 62 & \multirow{2}{*}{6.6} & \multirow{2}{*}{0.6} \\
\hline & & $\%$ & 0 & 0 & 0 & 0 & 5 & 33 & 62 & & \\
\hline \multirow{2}{*}{2.} & \multirow{2}{*}{$\begin{array}{l}\text { LIC offers policies with better range in } \\
\text { sum assured (min \& max) }\end{array}$} & $f$ & 0 & 0 & 0 & 0 & 11 & 42 & 47 & \multirow{2}{*}{6.4} & \multirow{2}{*}{0.7} \\
\hline & & $\%$ & 0 & 0 & 0 & 0 & 11 & 42 & 47 & & \\
\hline \multirow[t]{2}{*}{3.} & \multirow{2}{*}{$\begin{array}{l}\text { LIC offers Riders, Bonus etc with } \\
\text { almost all Life insurance products }\end{array}$} & $f$ & 0 & 0 & 13 & 5 & 16 & 26 & 40 & \multirow[t]{2}{*}{5.8} & \multirow[t]{2}{*}{1.4} \\
\hline & & $\%$ & 0 & 0 & 13 & 5 & 16 & 26 & 40 & & \\
\hline \multirow[t]{2}{*}{4.} & \multirow{2}{*}{$\begin{array}{l}\text { Life policies of LIC assures guarantee } \\
\text { loyalty Addition }\end{array}$} & $f$ & 7 & 4 & 0 & 0 & 31 & 51 & 7 & \multirow[t]{2}{*}{5.3} & \multirow[t]{2}{*}{1.5} \\
\hline & & $\%$ & 7 & 4 & 0 & 0 & 31 & 51 & 7 & & \\
\hline \multirow[t]{2}{*}{5.} & \multirow[t]{2}{*}{$\begin{array}{l}\text { LIC offers Loan facility on almost all } \\
\text { life Policies }\end{array}$} & $f$ & 0 & 0 & 4 & 9 & 10 & 25 & 52 & \multirow[t]{2}{*}{6.1} & \multirow[t]{2}{*}{1.2} \\
\hline & & $\%$ & 0 & 0 & 4 & 9 & 10 & 25 & 52 & & \\
\hline
\end{tabular}

Note: SA=Strongly Agree; A=Agree; SWA=Some What Agree; N=Neutral; SWD = Some What Disagree; $\mathrm{D}=$ Disagree; $\mathrm{SD}=$ Strongly Disagree.

Table No.4 depicts the information about officers Perception on the strategies followed to form marketing mix to sell the insurance products and services. It is clear from the above table that the mean value of all the elements of strategies are more than 5 and their standard deviation is less than 2 which indicates that marketing approaches are always interlinked with the product portfolio mix in the LIC.
At last it may be inferred the relation in between strategic marketing approach and product portfolio mix in LIC is there because the needs and desires, wants demands of customers are having volatility in there requisition. Hence it may become inevitable for the LIC to have a different strategic markets approaches based on product portfolio mix, to satisfy the customers. 


\section{Table No. 5 Respondents' opinion about consideration of marketing objectives before selling} policies:

$\mathbf{H}_{0}$ : There is no significant relation in between selling the policy by the agents or officers and convincing the policyholders, sufficient staff and computerised work.

$\mathbf{H}_{1}$ : There is significant relation in between selling the policy by the agents or officers and marketing objectives of the LIC.

\begin{tabular}{|c|c|c|c|c|c|c|c|c|c|}
\hline \multirow{2}{*}{$\begin{array}{l}\text { SI. } \\
\text { No }\end{array}$} & \multirow{2}{*}{ Marketing Objectives } & \multicolumn{2}{|c|}{ Always } & \multicolumn{2}{|c|}{$\begin{array}{c}\text { Occasionall } \\
y\end{array}$} & \multicolumn{2}{|c|}{ Never } & \multicolumn{2}{|c|}{ T- Test } \\
\hline & & $\mathbf{F}$ & $\%$ & f & $\%$ & $\mathbf{f}$ & $\%$ & $\begin{array}{l}\text { Mean Dif. } \\
\quad \& \text { df }\end{array}$ & Sign. \\
\hline 1 & $\begin{array}{l}\text { Spread of life insurance } \\
\text { message }\end{array}$ & 91 & 91.0 & 09 & 09.0 & 0 & 0.0 & $\begin{array}{l}1.090 \\
\mathrm{df}=99\end{array}$ & 0.000 \\
\hline 2 & $\begin{array}{l}\text { Mobilization of savings in } \\
\text { the form of premium }\end{array}$ & 76 & 76.0 & 24 & 24.0 & 0 & 0.0 & $\begin{array}{l}1.040 \\
d f=99\end{array}$ & 0.000 \\
\hline 3 & Improving customer service & 96 & 96.0 & 04 & 04.0 & 0 & 0.0 & $\begin{array}{l}1.070 \\
d f=99\end{array}$ & 0.000 \\
\hline 4 & $\begin{array}{l}\text { Increasing customer base } \\
\text { and its spread }\end{array}$ & 87 & 87.0 & 13 & 13.0 & 0 & 0.0 & $\begin{array}{l}1.130 \\
\mathrm{df}=99\end{array}$ & 0.000 \\
\hline 5 & Developing corporate image & 93 & 93.0 & 07 & 00.0 & 0 & 0.0 & $\begin{array}{l}1.380 \\
d f=99\end{array}$ & 0.000 \\
\hline 6 & Reporting a marginal profit & 66 & 66.0 & 30 & 30.0 & 4 & 4.0 & $\begin{array}{l}1.240 \\
\mathrm{df}=99\end{array}$ & 0.000 \\
\hline
\end{tabular}

The table No. 5 presents the information about consideration of marketing objectives before selling policies. It is clear from the above table that for all the above marketing objectives T-Test has been applied. For each objective degree of freedom is 99 and level of significance is 0.000 for the respective T-Value. Hence the null hypothesis has been rejected and accordingly alternative hypothesis i.e. there is significant relation in between selling the policy by the agents or officers and marketing objectives of the LIC has been accepted.

Ultimately it can be concluded that selling of policy by the agents or officers may become fruitful by convincing a policyholders for that they need sufficient staff, usage of modern ICT. Because presentation with PPT through videos, audios and some pictures exhibitions may helps to convince the customers in a pragmatic way to by the policy.

Table No. 6 Respondents' opinion about customer's future financial needs Vs development of appropriate insurance plans

$\mathbf{H}_{\mathbf{0}}$ : There is no significant relation in between policyholders' financial needs and LIC insurance plans.

$\mathbf{H}_{1}$ : There is significant relation in between policyholders' financial needs and LIC insurance plans.

\begin{tabular}{|c|c|c|c|c|c|c|c|c|}
\hline & & \multicolumn{6}{|c|}{ Customer's future financial needs } & \multirow[b]{2}{*}{ Chi-Square } \\
\hline & & $\begin{array}{l}\text { Old } \\
\text { Age }\end{array}$ & Death & Health & Income & $\begin{array}{l}\text { Family } \\
\text { tradition }\end{array}$ & Total & \\
\hline \multirow{5}{*}{ 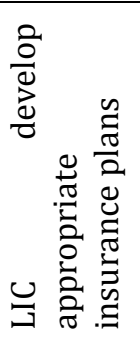 } & $\begin{array}{l}\text { Designing new } \\
\text { services/policies }\end{array}$ & 7 & 0 & 0 & 0 & 0 & 7 & \multirow{5}{*}{$\begin{array}{c}\chi 2=133.1 \\
d f=12 \\
P=0.000\end{array}$} \\
\hline & Innovate old once & 0 & 0 & 9 & 0 & 0 & 9 & \\
\hline & $\begin{array}{l}\text { Policies with } \\
\text { varied benefits }\end{array}$ & 6 & 0 & 0 & 0 & 7 & 13 & \\
\hline & $\begin{array}{l}\text { Changing needs of } \\
\text { customers }\end{array}$ & 10 & 4 & 0 & 11 & 46 & 71 & \\
\hline & Total & 23 & 4 & 9 & 11 & 53 & 100 & \\
\hline
\end{tabular}


The table no. 6exhibits the problems/difficulties in marketing life insurance products between Urban and Rural areas in the perspective of Officers. It is clear from the above table that, the calculated value of chi-squares' $\mathrm{P}$ Value is 0.000 at a 12 degree of freedom which is less than the standard level of significance i.e, 0.05 . Hence the null hypothesis has been rejected and accordingly alternative hypothesis has been accepted.

At last it may be summarize that the future financial needs and development of insurance plans are having a mutual relation. Because development of LIC plans should inspires and satisfy the future financial needs of customers, otherwise they may show there back towards LIC.

\section{CONCLUSION}

From the above discussion it is quite clear that Portfolio Management in LIC is good. Because of highly experienced, qualified office staff, hence this may be the real strength of LIC with which it's doing good business in the market and marketing approaches have been taken into consideration while forming the policies. The marketing approaches will have very important role to play to frame any policies keeping in mind of financial security, new service design, profit and satisfaction of policyholders. LIC officials take into consideration all the marketing strategies to improve customers service and policy services. It may be due to the reason that, it is marketing strategies which will be having a pioneer role to play to provide good services to customers and their policies services too to remain competent in the market.

\section{REFERENCE}

1. Mundra, Yogesh, "Insurance Prospective", Economic and Political weekly, Vol.23, no. 3, 2000, p-123-134.

2. Nikhil Gupta, "Responsible Reassurance", Septembe r 2001, P. 27-33.

3. Ziaudeen, A., A Project on "Marketing of Life Ins urance Services by Life Insurance Corporation of India at Thanjavur District”, 2008.

4. Varaprasad, V. and Murali Krishna, B., "Insurance Sector: Strategies for Intermediation and Marketing", Smart Journal of Business Management Studies.

5. $\quad$ R Guru Murthy(2012) "Life Assurance Industry In India: A Study On Marketing Strategies Of Indian Insurance Companies" Indian Journal Of Applied Research Volume : 2 | Issue : 2 | November 2012 | ISSN - 2249-555X.

6. Mushtaq Ahmad, Obaid-Ur-Rehman, International Journal of Management and Commerce Innovations ISSN 2348-7585 (Online), Vol. 3, Issue 2, pp: (507-510), Month: October 2015 - March 2016, Available at: www.researchpublish.com.
7. Staff, Investopedia (2003-11-25). "Portfolio Management". Investopedia. Retrieved 2018-1020. 